\title{
Diversity of the agricultural sector of the Russian economy: regularities of formation and development
}

\author{
Marina Kholodova ${ }^{1, *}$ and Evgeniya Krinichnaya $^{1}$ \\ ${ }^{1}$ Federal State Budget Scientific Institution «Federal Rostov Agricultural Research Centre» (FSBSI \\ FRARC), 346735, Institutskaya str. 1, p. Rassvet, Aksay district, Rostov region, Russia.
}

\begin{abstract}
The article deals with the main stages of formation and formation of a multi-layered rural economy in Russia. Presents the evolution of the development of multi-structured forms of farming in rural areas, depending on the degree of influence of the state on the economy of the agricultural sector of the country. It is proved that the key tools of state regulation of this issue are agrarian reforms, privatization, creation of an entrepreneurial environment, formation of an appropriate investment policy, and development of private land ownership institutions. The significant impulse for the development of modern forms of farming in the village was the choice of state priorities in the framework of the National project "Development of agriculture" were transformed into the state Program of development of agriculture, which allowed to strengthen its position as a major Agroholding structures and small-format sector. It is proved that sanctions and tendencies of the new economic reality amid the pandemic of the syndrome has led to the need to promote small agribusiness in rural areas, which will contribute to rural employment, development of rural infrastructure, growth of real monetary incomes of the population and middle class formation in rural areas.
\end{abstract}

\section{INTRODUCTION}

The agricultural sector of the national economy is a complex socio-economic system represented by a harmonious symbiosis of development of various forms of management and ownership, the effectiveness of which depends on the sustainable development of rural areas, the preservation of the historical appearance and territorial integrity of the country. Multiculturalism of agricultural production is a traditional form of development of industrial and economic relations in Russia.

The formation of a modern multi-structured agricultural economy in Russia was marked by a rather long process. Most economic scientists associate the development of a multilayered economy in rural areas with the transformation of production methods, which, due to their origin, rely on a different system of production and economic relations, characterizing certain socio-economic relationships of individual population groups according to certain economic characteristics. During the transition from one period to

* Corresponding author:kholodovama@rambler.ru 
another, any economic system forms its own dominant way of life, which differs primarily in property relations, the way production is organized (individual, family, collective), the social and legal status of employees, their participation in management, and others $[1 ; 2 ; 3]$.

The main feature of the formation of a multi-structured form of management in agriculture in Russia is the uneven development of its development. Thus, periods of gradual formation of key elements of the system of production and economic relations can be replaced by sharp fluctuations in the significant transformation of their properties, which is due to the active search for the optimal path of development, including through the death of the old or the birth of a new way of life.

\section{RESEARCH RESULT}

A review of literature sources has shown that state regulation of the economy, the purpose of which is to Express the interests of society, firms, and households, is a key tool for adapting the existing production and economic system to constantly changing economic conditions. Practice shows that the implementation of the main directions of the state socioeconomic policy can contribute to the transformation of the economic system, its improvement or elimination. At the same time, the formation of a new trajectory of socioeconomic development of society also causes cardinal shocks in the economic policy of the state. This fact is confirmed by the periods of" perestroika " of the economy of the USSR and modern Russia [1- 3].

Let us consider the main stages of the development of the diversity of agricultural production in Russia, based on the degree of influence of socio-economic processes in agrarian sector of the country (Fig.1). 
STRUCTURE OF SMALL-SCALE PRIVATE PEASANT ECONOMY AND PRIVATE-ECONOMIC

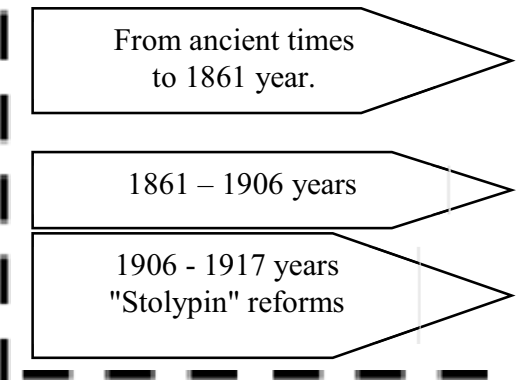

the emergence of sedentary agriculture before the formation of large princely and boyar farms using forced labor of peasants and semi-independent rural population

the exit of peasants from serfdom, the formation of peasant ownership of manor lands

development of farmers-entrepreneurs, capitalist relations and cooperation

\section{STRUCTURE OF STATE OWNERSHIP AND CENTRAL PLANNING}

\begin{tabular}{|c|c|c|}
\hline $1917-1920$ years & \multicolumn{2}{|c|}{$\begin{array}{l}\text { large peasant farms are subject to "dekulakization" and begin to develop in a } \\
\text { socialist direction; collective farms and state farms appear }\end{array}$} \\
\hline 1920 years & \multicolumn{2}{|c|}{$\begin{array}{l}\text { revision of ideas about the exceptional effectiveness of state ownership and the } \\
\text { existing management system; development of cooperation in various forms }\end{array}$} \\
\hline $\begin{array}{l}1920-1930 \text { years } \\
\text { industrialization }\end{array}$ & \multicolumn{2}{|c|}{$\begin{array}{l}\text { the ambiguous attitude of the authorities to the estate lands of the peasants } \\
\text { associated with the formation of socialism, there are restrictions in } \\
\text { management and infringement of the rights of the owner }\end{array}$} \\
\hline $1930-1987$ years & \multicolumn{2}{|c|}{$\begin{array}{l}\text { intensive development of private farms in the period of socialist } \\
\text { transformations of agriculture, expansion of the scale of activities of the }\end{array}$} \\
\hline $1987-1990$ years & \multicolumn{2}{|c|}{$\begin{array}{l}\text { formation of the regulatory framework for farmers ' development and } \\
\text { cooperation development }\end{array}$} \\
\hline \multicolumn{3}{|c|}{ A WAY OF LIFE BASED ON THE MARKET AND PRIVATE ENTREPRENEURSHIP } \\
\hline $1990-2000$ years & 2000- 2006 years & 2006 years - now \\
\hline $\begin{array}{l}\text { reorganization of agricultural } \\
\text { enterprises and formation of new } \\
\text { organizational and legal forms in } \\
\text { connection with changes in land } \\
\text { legislation, development of private } \\
\text { farms, trends in the decline of } \\
\text { agricultural production, which is } \\
\text { negatively affected }\end{array}$ & $\begin{array}{l}\text { stabilization of agricultural } \\
\text { production, establishment of the legal } \\
\text { status of LPH and K (f)X, } \\
\text { development of integration processes }\end{array}$ & $\begin{array}{l}\text { strengthening state regulation of } \\
\text { socio-economic processes in } \\
\text { agriculture, stimulating the } \\
\text { development of small-scale } \\
\text { businesses and agricultural } \\
\text { cooperation }\end{array}$ \\
\hline
\end{tabular}

Fig. 1. Stages of the development of mixed farms in AG-renom sector of the Russian economy

Thus, there are several stages in the development of multiculturalism in the agricultural sector of the Russian economy, the process of formation of which, for obvious reasons, was 
influenced by land use relations. In particular, from the time of settled agriculture in Kievan Rus to the abolition of serfdom, the agricultural population of the country could be classified according to different ways based on commodity farming and slave labor of slave peasants who worked in large princely, boyar, Church and monastery farms. Each period is characterized not only by the conditions of agricultural production, but also by the level of development, structure and trends. In Russia, the diversity of rural areas was represented by the smerdas-free peasantry, landowners-princes, Zemstvo and princely boyars, the peoplesemi-free rural population, the purchase-semi-independent rural population, etc.

The formation of private and communal land ownership continued after the abolition of serfdom in 1861. In tsarist Russia, the diversity in agriculture was represented by commodity peasant farms, Patriarchal, communal-tribal, landowners, private owners, monastic, Church, specific and other farms. During the" Stolypin " reforms, capitalist entrepreneurship based on wage labor and private property is developing. Special attention was paid to the development of cooperative activities and the structure of the state economy.

Thus, in the first decade of the twentieth century, when in the Russian Empire, in the conditions of increasing concentration of production and capital, the creation and successful functioning of monopolistic associations and industrial cooperatives, including the society of cotton mills, the Central Association of flax growing, the Siberian Union of meat-making artels, the Siberian oil-making cooperative, and others, large owners of land and capital made attempts to strengthen their influence in solving problems of coordination and organization of economic life that did not contradict state regulation, but they emphasize the danger of limiting entrepreneurial initiative $[4 ; 5 ; 6]$.

In 1917, the system of private-economic capitalism and small-scale private peasant farming was eliminated. On the basis of nationalized landlords ' lands, new forms of farms were created-state farms (Soviet farms).

The introduction of NEP stimulated the rapid growth of agricultural production, ensuring a sustainable food supply. There was a transformation of the organizational and economic structure. The main agricultural producers, in addition to state farms, were also collective farms (collective farms), which enjoyed significant state support, and their functioning was based on state ownership of land. During this period, the country begins to actively develop cooperation in various forms of its manifestation, demonstrating significant results of agricultural production.

During the war years and up to 1958, the country actively developed personal farms of the population - their land plots increased by 3 times, and their profitability - by $50 \%$. In 1989 , the legality of small forms of farming was officially recognized.

In 1990, The law "on peasant (farm) farming" and other legal acts created the legal basis for the development of farming. The second birth of the cooperative movement begins with the adoption of the law of the USSR of 26.05.1988. "On cooperation in the USSR", which defines the economic, organizational and legal basis for the activity of cooperatives. By the beginning of 1990, there were 193 thousand of them, with about 5 million employees.

In economic theory, the development of multi-structured forms of management in rural areas is traditionally identified with the phenomenon of a transitional economy. Thus, the new economic policy of the 90's, which presupposes a radical reform of property relations and a transition to market relations, revealed the inability of the collective-state farm system to function in the new economic conditions. There were legislative acts on the reform of collective farms, state farms, the creation of new forms of way of life, farms based on them. Thus, there was a rapid elimination of the economic structure based on state ownership and centralized planning. At the same time, a way of life was formed based on market relations, in which the Central place was occupied by private entrepreneurial initiative. 
Privatization, creation of an entrepreneurial environment, formation of appropriate investment policy, development of institutions that give preference to one way of life, and sanctioned opposition to others have become key state tools that contribute to the formation of modern multi-structure $[1 ; 2 ; 6]$

In 1992, a new stage in the history of the development of the agricultural economy began. Most collective farms and state farms became the basis for the emergence of jointstock companies, partnerships, other private agricultural organizations, $\mathrm{K}(\mathrm{f}) \mathrm{X}$, associations, unions, production cooperatives, and others. With the beginning of liberal and radical reforms, the state re-established the institution of private land ownership. About 12 million villagers have become owners of land shares, and up to 44 million families have land in private ownership. There were 280 thousand peasant (farmer) farms in the country. The role of private subsidiary farms of the population has significantly increased. In 1992, the structure of production by categories of farms is: agricultural organizations- $67.1 \%$, households-31.8\%, K(f) X - $1.1 \%$. however, large-scale privatization in rural areas in terms of production and infrastructure development could not replace the state economy in full, which lost not only its main features, but was also destroyed, complicating the crisis of the national economy in General, and agricultural production in particular. Despite the emergence of various organizational and legal forms of ownership in the country's agricultural production, the implementation of the state strategy of liberalization did not create a multi-structure in the agricultural sector.

A significant direction of the reform of a comprehensive change in the system of agricultural relations, affecting the legal, economic, social, organizational and other aspects of economic activity in agriculture, was the formation of a multi-structured rural economy, based on improving land relations, the formation of new organizational and legal forms of management that meet market conditions, the development of private property, integration and cooperation processes in the agro-industrial complex.

Thus, by the beginning of 2000 , the country was supporting the development of agroholdings - large farms that can ensure the country's food security. The government of the Russian Federation sets a goal for further "formation of an effective multi-structured agricultural sector of the economy". In 2003, the laws "on peasant (farm) farming" and "on personal subsidiary farming" were adopted.

Since 2006, the diversity of the Russian agricultural economy has been characterized by specific features, which is associated with trends in strengthening state regulation of socioeconomic processes, including in agriculture. Thus, Federal law No. 264-FZ "on the development of agriculture", adopted in 2006, defined the main goals of agricultural policy at the present stage, principles, priorities and tools for their implementation. The agriculture Ministry in the framework of the law, we developed and implemented a national project "Development of agriculture" were transformed into the State program of development of agriculture and regulation of markets of agricultural products, raw materials and food for 2008-2012" which has been created the preconditions for the sustainable development of small forms of managing in agriculture.

Discussing the fundamental changes in the policy of state regulation of socio-economic development of the agricultural sector of Russia, Tarasov A. N. describe the national project "Development of agriculture" as a production program to support technical and technological modernization of agriculture ("Accelerated livestock development"), development of market infrastructure in rural areas (consumer cooperatives), mitigating social risks of the forthcoming accession to the WTO (stimulating the development of small farms"), overcoming the demographic crisis ("housing for young families") [164].

A retrospective analysis of development during the period of radical changes in rural areas has shown that modern forms of management, as a complex socio-economic system, have undergone significant organizational and economic changes in their evolution. Each 
form of management, occupying its own "niche", in optimal combination with others provides conditions for the effective functioning of agricultural production (Fig. 2).

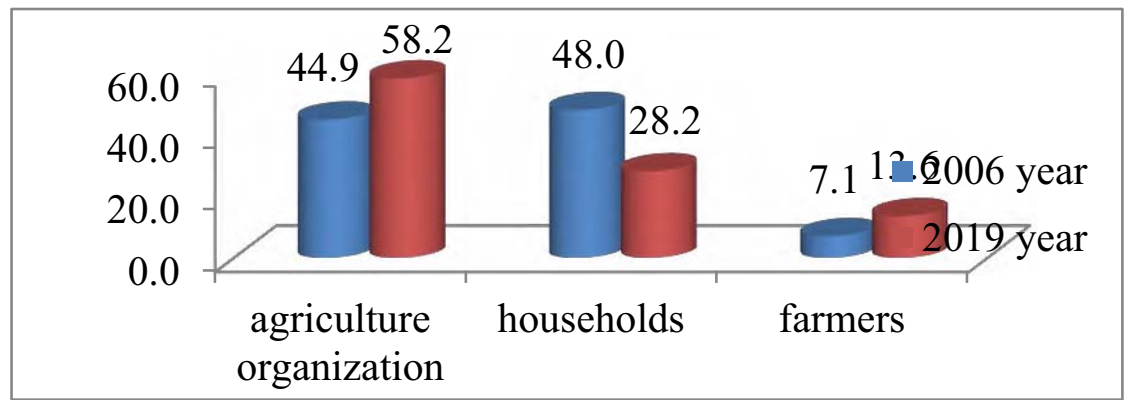

Fig. 2. Structure of agricultural production in Russia in 2006 and 2019 by category of farms, \% [7]

So, in a number of industries, in connection with the implementation of the national Project and state Programs, competitive production continues to be formed, in particular, in pig and poultry farming, large formations have been developed (Fig. 3), operating on an innovative basis with the attraction of foreign investment $[8 ; 9]$.

At the same time, among the programs implemented in the country in small agribusiness, grant support for beginning farmers, family livestock farms and agricultural consumer cooperatives has become the most widespread. The priority of grant programs was the development of dairy farming, as the most capital-intensive industry that requires significant financial investments. During the program's operation, farmers purchased livestock of highly productive farm animals, purchased machinery and livestock equipment [8;9]. Land plots and production facilities were purchased for doing business. In the light of current events, the share of milk production in the Russian agricultural Sector increased from $3.6 \%$ to $8.5 \%$ over the period 2006-2019 [7].

The crisis of the dairy cattle industry lies in the specifics of the industry. The reduction in the total number of cows is primarily due to the unprofitability of milk production due to the existing disparity in prices for the products of the industry and processed products, the unsatisfactory state of the breed composition of the herd, the provision of balanced feed, and the mandatory availability of agricultural land for the dairy cattle industry.

The use of innovative technologies in feeding, keeping farm animals, updating the gene pool and breeding base is currently under the power of large agricultural organizations in the country, which has a positive impact on the gross volume of its production $(53.1 \%$ of the total production in the country) (Fig. 3).

No less significant is the contribution of households to the production of basic types of food. Thus, in 2019, they accounted for more than $35.0 \%$ of milk production, $55.1 \%$ of vegetables, $69.0 \%$ of potatoes, and $18.0 \%$ of meat (Fig. 3 ). 


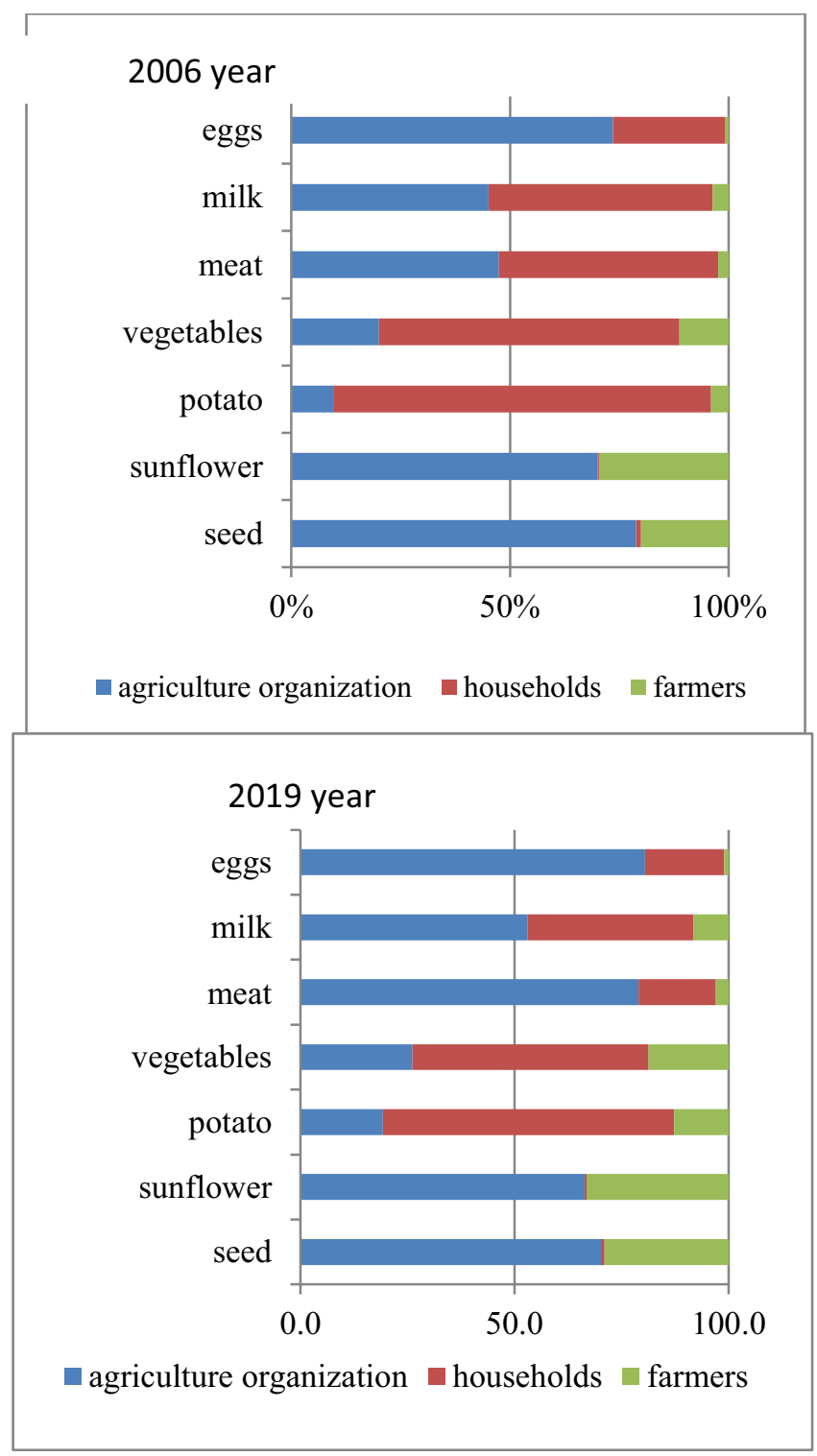

Fig. 3. Structure of production of the main types of agricultural products in Russia in 2006 and 2019 by categories of farms, $\%$ [7]

At the present stage of development of the Russian agricultural economy, characterized by the sanctions regime, trends in the manifestation of a new economic reality against the background of a pandemic syndrome, and affecting the functioning of agricultural production, there is a vector of structural changes aimed at strengthening the positions of large agricultural holding structures, as well as the development of a small-format sector and on the basis of agricultural consumer cooperation, the most important task of which is not only to improve the efficiency of farmers, but also in expanding the participation of small agribusiness entities in providing the population with food of their own production within each region [8- 11].

Analysis of the current state of the agricultural sector of the economy showed that the country has a tendency to consolidate farms by land area, both among large-scale and 
small-format agribusiness (Fig. 4) [12-13].

According to the BELF consulting company, in 2019, the 25 largest land owners accounted for 10 million hectares. At the same time, agricultural holdings sowed 7.9 million hectares of sown area, or $15.0 \%$ of all farms in Russia. At the same time, the" entrance ticket " of the rating increased from 107 thousand hectares in 2018 to 142 thousand hectares in 2019 per agricultural holding [14].

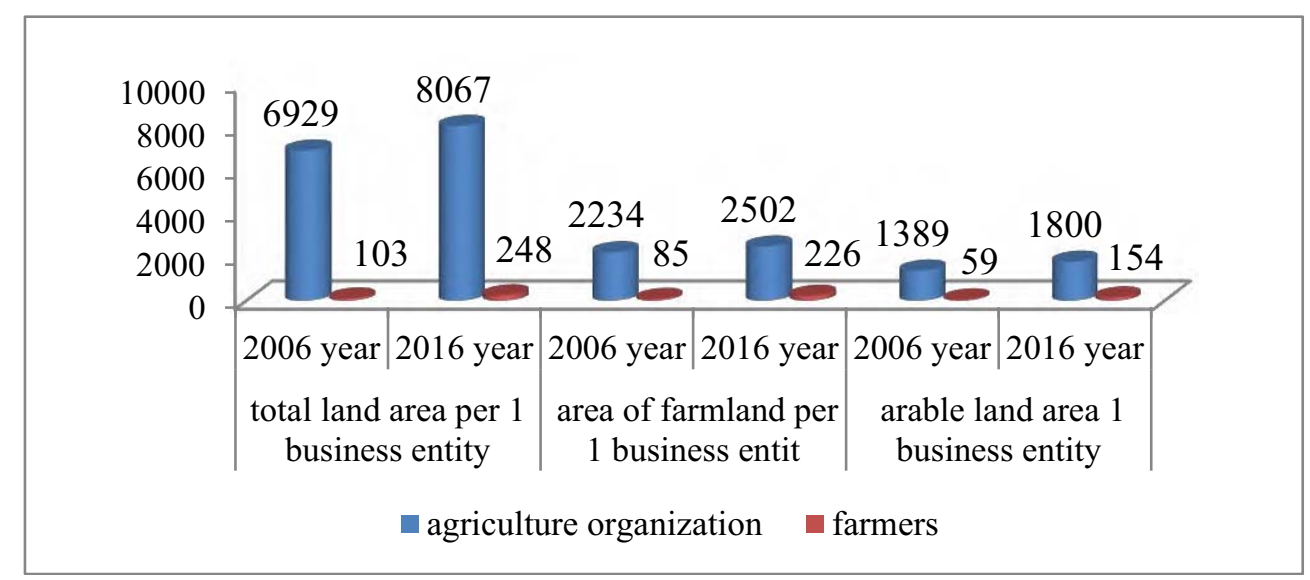

Fig. 4. Dynamics of land and agricultural land belonging to 1 farm, in the context of certain categories of farms in the agricultural sector of Russia [7]

It should be noted that the advantages of large-scale agro-industrial production over small-format are the rational use of land, labor, financial resources, modern innovative equipment and technologies, the possibility of attracting additional investment, the effect of a scale effect aimed at reducing costs per unit of production, the development of logistics infrastructure, the ability to sell products of their own production through large retailers, including Auchan, Lenta, OK, Magnit, Pyaterochka, apex, Assorted, and others.

Therefore, a serious problem hindering the further development of small agribusiness in rural areas is their small size, which does not allow them to compete with the "sharks" of the food market.

Conditions of fierce competition force medium and small agricultural producers to pay special attention to their business development strategy, which leads to the need to search for alternative markets for products through the system of agricultural consumer cooperation, which has proven its effectiveness in various socio-economic systems. Note that this process requires time and active support from the state. Since the effective functioning of small businesses in rural areas contributes not only to ensuring food security of the country and the dynamic development of rural areas.

\section{Conclusion}

It is already clear that the development of large and small agribusiness in the country contributes not only to ensuring food security of the country, but also the development of mixed forms of farming in rural areas, rural employment, improving rural infrastructure, dynamic growth of real money up-stroke population and middle class formation in remote rural areas, the preservation of historical heritage. 


\section{References}

1. O. Isaeva, M. Kabanenko, A. Chistyakov, L. Dubrova, N. Filin, E3s Web of Conferences, 175, 13004 (2020) doi: 10.1051/e3sconf/202017513022

2. M. Kholodova, M. Kabanenko, L. Orekhova, L. Dubrova, Z. Kolycheva, E3s Web of Conferences, 175, 13004 (2020) doi:10.1051/e3sconf/202017513004

3. T. Kushnarenko, A. Tabakov, I. Fomina, A. Khachatryan, V. Prosandeev, O. Kholodov, IOP Conference Series: Earth and Environmental Science, 403(1) (2019) doi: 10.1088/1755-1315/403/1/012074

4. O. Frolova, Successes of modern science and education, 22(3), 421-431 (2011) doi: 10.21443 / 1560-9278-2019-22-3-421-431

5. L. N. Usenko, Y. G. Chernysheva, V. A. Guzey, O. M. Todorova, A. M. Usenko, International journal of trade and global markets, 2-3, 160-167 (2017) doi: 10.1504/ijtgm.2017.086074

6. Web Portal of Federal state statistics service. Retrieved from: http: www.gks.ru. (Last access 12.07.2020)

7. M. Slozhenkina, I. Gorlov, M. Kholodova, O. Kholodov, O. Shakhbazova, D. Mosolova, AGRITECH-III-2020 IOP Publishing IOP Conf. Series: Earth and Environmental Science, 548 (2020) doi:10.1088/1755-1315/548/8/082037

8. T. G. Gurnovich, L. V. Agarkova, E. A. Ostapenko, L. N. Usenko, International journal of engineering and technology(uae), 7( 4.25), 201-211 (2018)

9. S. K. Wegren, Journal of Eurasian Studies, 3(2), 193-202 (2012)

10. Z. A. Voitleva, Vestnik of Murmansk state technical university, 22(3), 421-431 (2019) doi: 10.21443/1560-9278-2019-22-3-421-431.

11. V. Uzun, N. Shagaida, Z. Lerman, Land Use Policy, 83, 475-487 (2019) doi: /10.1016/j.landusepol.2019.02.018

12. M. Y. Veselovsky, M. A. Izmailova, A. V. Bogoviz, S. V. Lobova, A. N. Alekseev, Quality - access to success, 19(162), 60-66 (2018)

13. R. F. Gataullin, A. A. Askarov, G. N. Khuzhakhmetova, N. V. Yarkov, Economic Region, 2, 271-284 (2015) doi 10.17059/2015-2-22

14. I. Boldyreva, O. Andryushchenko, A. Nikitaeva, Z. Udalova, J. Rudash, Journal of environmental management and tourism, 8, 4(20), 642-647 (2017) doi:10.14505/ jemt.v8.3(19). 15 